\title{
PENGEMBANGAN PERANGKAT PEMBELAJARAN DENGAN PENDEKATAN CONTEXTUAL TEACHING AND LEARNING UNTUK MENINGKATKAN MOTIVASI DAN HASIL BELAJAR BAGI SISWA KELAS IV SEKOLAH DASAR
}

\author{
Rizky Nugroho $^{1}$, Mustaji ${ }^{2}$, Suhanadji $^{3}$ \\ Universitas Negeri Surabaya ${ }^{1,2,3}$ \\ rizky.nugroz@gmail.com ${ }^{1}$
}

\begin{abstract}
Abstrak
Penelitian ini bertujuan untuk menghasilkan perangkat pembelajaran dengan menggunakan pendekatan Contextual Teaching and Learning (CTL) yang valid, praktis, dan efektif bagi siswa kelas IV SD. Penelitian ini merupakan penelitian pengembangan dengan menggunakan model pengembangan 4D yang meliputi empat tahap mendefinisikan, mendesain, mengembangkan dan menyebarluaskan. Hasil penelitian menunjukkan bahwa perangkat pembelajaran dinyatakan valid dengan kategori sangat baik oleh validator. Penerapan perangkat pembelajaran dapat terlaksana dengan kategori sangat baik dan respon siswa terhadap perangkat pembelajaran berada pada kategori sangat baik. Terdapat perbedaan motivasi belajar dan hasil belajar yang signifikan antara kelas eksperimen yang menggunakan perangkat pembelajaran dengan pendekatan Contextual Teaching and Learning dan kelas kontrol yang tidak menggunakan perangkat pembelajaran hasil pengembangan. Berdasarkan hasil penelitian, dapat disimpulkan bahwa pengembangan perangkat pembelajaran dengan menggunkan pendekatan Contextual Teaching and Learning memenuhi kriteria valid, praktis, dan efektif untuk meningkatkan motivasi dan hasil belajar bagi siswa kelas IV SD.
\end{abstract}

Kata Kunci: Perangkat Pembelajaran, Contextual Teaching and Learning

\begin{abstract}
This research aims to produce learning materials using the Contextual Teaching and Learning approach (CTL) that is valid, practical, and effective for fourth grade of elementary school. This research is a development study using 4-D development model which includes four stages of define, design, develop and disseminate. The result of the research shows that learning materials is valid with very good category by validator. Implementation of learning materials can be done with very good category and students responses to learning materials is in very good category. There are differences in learning motivation and significant learning result between experimental classes using learning materials using the Contextual Teaching and Learning approaches and control classes that do not use learning materials result of development. Based on the results of the study, it can be concluded that the development of learning materials using the Contextual Teaching and Learning approach fulfills the valid, practical, and effective criteria.
\end{abstract}

Keywords: Learning Materials, Contextual Teaching and Learning 


\section{PENDAHULUAN}

Perangkat pembelajaran adalah hal-hal yang harus dipantau sehingga pelaksanaan pembelajaran lebih terarah untuk mencapai kompetensi yang diharapkan(Rusman, 2014). Perangkat pembelajaran dapat berupa: Rencana Pelaksanaan Pembelajaran (RPP), Lembar Kerja Peserta Didik (LKPD), Bahan Ajar Siswa, dan Tes Hasil Belajar (THB). Pentingnya perangkat pembelajaran dalam kegiatan belajar mengajar sehingga setiap guru hendaknya mampu mengembangkan perangkat pembelajaran.

Berdasarkan hasil observasi di kelas IV SDN Hendrosari Kecamatan Menganti Kabupaten Gresik, terdapat kendala dalam proses pembelajaran yaitu guru masih menggunakan metode ceramah dalam menyampaikan pembelajaran. Guru belum menggunakan media pembelajaran yang sesuai, sehingga siswa kurang tertarik mengikuti pembelajaran. Pembelajaran masih berpusat pada guru sehingga kegiatan pembelajaran menjadi kurang efektif karena siswa menjadi pasif karena hanya mendengar informasi dari guru. Selain itu hasil belajar siswa belum maksimal, banyak siswa yang memperoleh nilai di bawah Kriteria Ketuntasan Minimal (KKM) yang telah ditetapkan yaitu 70.

Pembelajaran Contextual Teaching and Learning memudahkan siswa memahami materi ajar. Motivasi siswa pada pembelajaran Contextual Teaching and Learning juga mengalami peningkatan. Siswa semangat mengikuti pembelajaran karena pembelajaran yang diterapkan berkaitan dengan kehidupan keseharian siswa (Amuntu, Rede, \& Pasaribu, 2016). Berdasarkan hasil penelitian terdahulu,dapat disimpulkan bahwa pendekatan Contextual Teaching and Learning dapat meningkatkan motivasi siswa dalam mengikuti pembelajaran sehingga hasil belajar siswa menjadi meningkat.

Sesuai dengan teori Piaget yang menyatakan bahwa tingkat perkembangan intelektual anak sekolah dasar yang masih dalam tahap operasional konkret (Suprijono, 2014). Berdasarkan uraian di atas diharapka pengembangan perangkat pembelajaran dengan pendekatan Contextual Teaching and Learning dapat meningkatkan motivasi dan hasil belajar bagi siswa kelas IV sekolah dasar”. 


\section{METODE PENELITIAN}

Subjek uji coba dalam penelitian pengembangan ini adalah siswa kelas IV SDN Hendrosari semester 2 tahun pelajaran 2017/2018. Subjek uji coba 1 (uji kelompok kecil) adalah 10 siswa terdiri dari 5 siswa kelas IV-A dan 5 siswa kelas IV-B yang dipilih secara acak. Subjek uji coba 2 (uji coba lapangan) adalah 40 siswa yang terdiri dari 20 siswa kelas IV-A sebagai kelas eksperimen dan 20 siswa kelas IV-B sebagai kelas kontrol.Uji coba produk dilakukan dengan dua tahap, yaitu dengan uji coba 1 (uji coba kelompok kecil) dan uji coba 2 (uji coba lapangan). Uji coba lapangan dengan menggunakan desain eksperimen nonequivalent control group design.

Instrumen untuk mengumpulkan data yang digunakan dalam penelitian ini adalah lembar validasi, lembar observasi, angket, tes hasil belajar. Analisis kelayakan perangkat pembelajaran dilakukan melalui lembar validasi. Hasil validasi kemudian diubah menjadi persentase dan diklasifikasikan ke dalam beberapa kategori interpretasi. Analisis kepraktisan perangkat pembelajaran dilakukan melalui lembar observasi pada proses pembelajaran, aktivitas siswa, dan angket respon siswa. Hasil lembar observasi dan angket kemudian diubah menjadi persentase yang diklasifikasikan ke dalam beberapa kategori interpretasi. Selanjutnya, analisis keefektifan perangkat pembelajaran dapat dilihat melalui angket motivasi belajar dan tes hasil belajar siswa.

\section{HASIL DAN PEMBAHASAN}

Penelitian pengembangan ini bertujuan untuk menghasilkan perangkat pembelajaran dengan menggunkan pendekatan Contextual Teaching and Learning pada tema daerah tempat tinggalku bagi kelas IV SD yang valid, praktis, dan efektif. Perangkat pembelajaran tersebut meliputi Rencana Pelaksanaan Pembelajaran (RPP), Lembar Kerja Peserta Didik (LKPD), Bahan Ajar Siswa, dan Tes Hasil Belajar (THB).

Hasil dari kevalidan perangkat pembelajaran dengan menggunakan pendekatan Contextual Teaching and Learning diperoleh dari lembar validasi perangkat pembelajaran yang diisi oleh validator. Pada tahap validasi dilakukan 
penilaian terhadap perangkat pembelajaran yang diberikan oleh validator. Selain itu dilakukan revisi hasil validasi dengan cara menelaah masukan diberikan oleh validator dan melakukan perbaikan perangkat pembelajaran berdasarkan masukan oleh validator. Hasil validasi perangkat pebelajaran yang meliputi RPP, Bahan Ajar Siswa, Lember Kerja Peserta Didik, dan Tes Hasil Belajar disajikan pada tabel I.

Tabel 1. Hasil Validasi Perangkat Pembelajaran

Data Diolah, 2018

\begin{tabular}{lcc}
\hline Lembar Validasi & Persentase & Kategori \\
\hline RPP & 91 & Sangat Baik \\
\hline LKPD & 86 & Sangat Baik \\
\hline Bahan Ajar Siswa & 88 & Sangat Baik \\
\hline Tes Hasil Belajar & 86 & Sangat Baik \\
\hline
\end{tabular}

Berdasarkan tabel 1, diketahui hasil validasi RPP memperoleh persentase $91 \%$, LKPD memperoleh persentase $86 \%$, Bahan Ajar memperoleh persentase $86 \%$, dan Tes Hasil Belajar memperoleh persentase $86 \%$. Berdasarkan pengkategorian kevalidan perangkat pembelajaran, RPP, LKPD, Bahan Ajar dan Tes Hasil belajar dapat dinyatakan valid dengan kategori sangat baik.

Hasil kepraktisan perangkat pembelajaran dengan menggunakan pendekatan Contextual Teaching and Learning dapat diperoleh dari lembar observasi keterlaksanaan pembelajaran dan angket respon yang diisi oleh para siswa. Lembar pengamatan keterlaksanaan pelaksanaan pembelajaran digunkan untuk mengetahui kesesuaian antara proses pembelajaran dengan RPP. Sedangkan lembar angket respon siswa digunakan untuk mengetahui respon awal dan ketertarikan siswa terhadap perangkat pembelajaran. Hasil lembar observasi keterlaksanaan pembelajaran sajikan pada tabel 2.

Tabel 2. Hasil Keterlaksanaan Pembelajaran

\begin{tabular}{ccc}
\hline Pertemuan & Persentase & Kategori \\
\hline 1 & 88 & Sangat Baik \\
\hline 2 & 88 & Sangat Baik \\
\hline 3 & 89 & Sangat Baik \\
\hline 4 & 90 & Sangat Baik \\
\hline 5 & 91 & Sangat Baik \\
\hline 6 & 92 & Sangat Baik \\
\hline Rata-Rata & 89 & Sangat Baik \\
\hline & & Data Diolah, 2018
\end{tabular}


Berdasarkan tabel 2, diketahui persentase keterlaksanaan pembelajaran pada pertemuan 1 sebesar $88 \%$, pertemuan 2 sebesar $88 \%$, pertemuan 3 sebesar $89 \%$, pertemuan 4 sebesar $90 \%$, pertemuan 5 sebesar $91 \%$, dan pertemuan 6 sebesar $92 \%$. Dari keenam pertemuan tersebut diperoleh persentase rata-rata keterlaksanaan pembelajaran yang dilaksanakan sebesear $89 \%$ dan dapat dikategorikan keterlaksanaan pembelajaran yang menggunakan pendekatan Contextual Teaching and Learning adalah sangat baik.

Angket respon siswa terhadap perangkat pembelajaran diberikan kepada siswa setelah pembelajaran selesai dilaksanakan. Angket respon siswa diberikan pada saat uji coba terbatas dan uji coba lapangan. Tahap uji coba pertama yaitu uji coba terbatas yang terdiri dari 10 responden dan uji coba lapangan terdiri dari 20 responden. Hasil angket respon siswa terhadap perangkat pembelajaran pada uji coba terbatas dan lapangan dapat dilihat pada tabel 3.

Tabel 3. Hasil Angket Respon Siswa

\begin{tabular}{ccc}
\hline Uji Coba & Persentase & Kategori \\
\hline Terbatas & 89 & Sangat Baik \\
\hline Lapangan & 92 & Sangat Baik \\
\hline & \multicolumn{3}{c}{ Data Diolah, 2018 }
\end{tabular}

Berdasarkan tabel 3, diketahui bahwa persentase yang diperoleh untuk angket respon siswa dalam uji coba terbatas adalah sebesar $89 \%$ dengan kategori sangat baik. Persentase diperoleh untuk angket respon siswa dalam uji coba lapangan adalah sebesar $92 \%$ dengan kategori sangat baik. Hal ini menunjukkan bahwa siswa tertarik dengan perangkat pembelajaran dengan pendekatan Contextual Teaching and Learning yang dikembangkan.

Hasil keefektifan perangkat pembelajaran dengan menggunakan pendekatan Contextual Teaching and Learning dapat diperoleh dari peningkatan motivasi dan hasil belajar siswa. Hasil pretest dan posttest akan diuji dengan t-test untuk mengetahui efektivitas perangkat pembelajaran dengan menggunakan pendekatan Contextual Teaching and Learning. Namun, sebelum diuji menggunakan t-test, terlebih dahulu dilakukan uji normalitas dan uji homogenitas. Uji normalitas dan uji homogenitas dilakukan untuk mengetahui data tersebut berdistribusi normal atau tidak. Uji normalitas dilakukan menggunakan uji statistik Shapiro-Wilk dengan bantuan program SPSS 23. Kriteria pengujiannya adalah jika nilai 
signifikansi yang diperoleh lebih dari $\alpha=0,05$ maka data memiliki sebaran distribusi normal dan jika nilai signifikansi yang diperoleh kurang dari $\alpha=0,05$ maka sebaran data tidak berdistribusi normal. Hasil uji normalitas data motivasi belajar dan hasil belajar siswa disajikan pada tabel 4 .

Tabel 4. Hasil Uji Normalitas

\begin{tabular}{ccccc}
\hline Kelas & Uji Normalitas & Sig & $\boldsymbol{\alpha}$ & Keputusan Uji \\
\hline Eksperimen & Angeket Motivasi Awal & 0,122 & 0,05 & Normal \\
\cline { 2 - 5 } & Angket Motivasi Akhir & 0,434 & 0,05 & Normal \\
\cline { 2 - 5 } & Pretest Hasil Belajar & 0,430 & 0,05 & Normal \\
\cline { 2 - 5 } & Posttest Hasil Belajar & 0,082 & 0,05 & Normal \\
\hline \multirow{3}{*}{ Antrol } & Angeket Motivasi Awal & 0,271 & 0,05 & Normal \\
\cline { 2 - 5 } & Angket Motivasi Akhir & 0,221 & 0,05 & Normal \\
\cline { 2 - 5 } & Pretest Hasil Belajar & 0,199 & 0,05 & Normal \\
\cline { 2 - 5 } & Posttest Hasil Belajar & 0,356 & 0,05 & Normal \\
\hline & & \multicolumn{3}{c}{ Data Diolah, 2018 }
\end{tabular}

Berdasarkan data pada tabel 4, dapat disimpulkan bahwa data terdistribusi normal. Setelah melakukan uji normalitas, langkah selanjutnya adalah melakukan uji homogenitas untuk mengetahui apakah kedua kelas itu homogen atau tidak. Uji homogenitas dilakukan menggunakan uji statistik Lavene Statistic dengan bantuan program SPSS 23. Kriteria pengujiannya adalah jika nilai signifikansi (p) yang diperoleh lebih dari $\alpha=0,05$ maka data memiliki varian yang homogen dan jika nilai signifikansi yang diperoleh kurang dari $\alpha=0,05$ maka memiliki varian yang tidak homogen. Hasil uji homogenitas data motivasi dan hasil belajar siswa disajikan pada tabel 5 .

Tabel 5. Hasil Uji Homogenitas

\begin{tabular}{ccccc}
\hline Kelas & Uji Homogenitas & Sig & $\boldsymbol{\alpha}$ & Keputusan Uji \\
\hline \multirow{2}{*}{$\begin{array}{c}\text { Eksperimen } \\
\text { Kontrol }\end{array}$} & Angket Motivasi Awal & 0,131 & 0,05 & Homogen \\
\cline { 2 - 5 } & Angket Motivasi Akhir & 0,804 & 0,05 & Homogen \\
\cline { 2 - 5 } & Pretest Hasil Belajar & 0,926 & 0,05 & Homogen \\
\cline { 2 - 5 } & Posttest Hasil Belajar & 0,318 & 0,05 & Homogen \\
\hline & & & \multicolumn{2}{c}{ Data Diolah, 2018 }
\end{tabular}

Berdasarkan data pada tabel 5, dapat disimpulkan bahwa kelas eskperimen dan kelas kontrol homogen. Setelah mengetahui bahwa data yang didistribusikan di kedua kelas itu normal dan homogen, langkah selanjutnya adalah melakukan uji-t. Uji T dilakukan menggunakan uji statistik independent sample t-test dengan bantuan SPSS 23. Kriteria pengujiannya adalah jika nilai sig. (2-tailed) yang diperoleh lebih dari $\alpha=0,05$ maka $\mathrm{H}_{\mathrm{o}}$ diterima dan jika nilai sig. (2-tailed) yang 
diperoleh kurang dari $\alpha=0,05 \mathrm{H}_{\mathrm{o}}$ ditolak. Hasil uji t data motivasi dan hasil belajar siswa disajikan pada Tabel 6 .

Tabel 5. Hasil Uji T

\begin{tabular}{ccccc}
\hline Kelas & Uji Homogenitas & Sig & $\boldsymbol{\alpha}$ & Keputusan Uji \\
\hline Eksperimen & Angket Motivasi Awal & 0,618 & 0,05 & $\mathrm{H}_{\mathrm{o}}$ diterima \\
\cline { 2 - 5 } Kontrol & Pretest Hasil Belajar & 0,597 & 0,05 & $\mathrm{H}_{\mathrm{o}}$ diterima \\
\cline { 2 - 5 } & Angket Motivasi Akhir & 0,000 & 0,05 & $\mathrm{H}_{\mathrm{o}}$ ditolak \\
\cline { 2 - 5 } & Posttest Hasil Belajar & 0,0001 & 0,05 & $\mathrm{H}_{\mathrm{o}}$ ditolak \\
\hline & & \multicolumn{3}{c}{ Data Diolah, 2018 }
\end{tabular}

Berdasarkan data pada tabel VII, diketahui uji t angket motivasi awal antara kelas eksperimen dan kelas kontrol menunjukkan bahwa nilai sig. (2-tailed) posttest motivasi belajar siswa sebesar 0,618>0,05 maka keputusan uji adalah $\mathrm{H}_{\mathrm{o}}$ diterima dan $\mathrm{H}_{\mathrm{a}}$ ditolak, sedangkan nilai sig. (2-tailed) posttest hasil belajar siswa sebesar 0,597 > 0,05 maka keputusan uji adalah $\mathrm{H}_{\mathrm{o}}$ ditolak dan $\mathrm{H}_{\mathrm{a}}$ diterima. Berdasarkan hasil ini, dapat disimpulkan tidak ada perbedaan yang signifikan antara motivasi dan hasil belajar siswa di kelas eksperimen yang menerapkan pembelajaran menggunakan pendekatan Contextual Teaching and Learning dengan kelas kontrol yang menerapkan pembelajaran konvensional.

Hasil uji t angket motivasi akhir antara kelas eksperimen dan kelas kontrol menunjukkan bahwa nilai sig. (2-tailed) posttest motivasi belajar siswa sebesar $0,001<0,05$ maka keputusan uji adalah $\mathrm{H}_{\mathrm{o}}$ ditolak dan $\mathrm{H}_{\mathrm{a}}$ diterima, sedangkan nilai sig. (2-tailed) posttest hasil belajar siswa sebesar 0,001 $<0,05$ maka keputusan uji adalah $\mathrm{H}_{\mathrm{o}}$ ditolak dan $\mathrm{H}_{\mathrm{a}}$ diterima.

Berdasarkan hasil penelitian, motivasi belajar siswa di kelas eksperimen mengalami peningkatan motivasi belajar lebih tinggi daripada kelompok kontrol karena menerima pembelajaran dengan pendekatan Contextual Teaching and Learning. Pendapat tersebut didukung oleh Majid yang menyatakan pendekatan Contextual Teaching and Learning adalah suatu proses pendidikan yang holistik dan bertujuan memotivasi siswa untuk memahami makna materi pelajaran yang dipelajarinya dengan mengaitkan materi tersebut dengan konteks kehidupan sehari-hari (Majid, 2013). Di dalam pembelajaran Contextual Teaching and Learning terdapat kegiatan-kegiatan seperti pemodelan, tanya jawab, masyarakat belajar yang melibatkan keaktifan siswa dalam mengkaitkan materi dengan 
pengalaman siswa, sehingga siswa lebih termotivasi dalam mengikuti kegiatan pembelajaran.

Hasil penelitian juga menunjukkan bahwa kelas eksperimen mengalami peningkatan hasil belajar lebih tinggi daripada kelas kontrol. Pembelajaran dengan menggunakan model pembelajaran Contextual Teaching and Learning pada tema daerah tempat tinggalku dapat meningkatkan hasil belajar siswa. Pada pembelajaran Contextual Teaching and Learning Guru mengembangkan materi pelajaran dengan mengkonstruksi pengetahuan baru siswa dan mengaitkannya dalam kehidupan siswa melalui tanya jawab tentang materi yang sedang dibahas. Kontruktivisme dalam pendekatan Contextual Teaching and Learning menekankan bahwa siswa sangat penting untuk terlibat langsung dalam membangun pengetahuannya sendiri, sehingga proses pembelajaran yang terjadi lebih berpusat pada siswa (Sujana, 2014). Hal tersebut sesuai teori Ausubel yang mengemukakan bahwa untuk mengoptimalkan perolehan, pengorganisasian, serta pengungkapan pengetahuan baru dapat dilakukan dengan membuat pengetahuan baru itu bermakna bagi siswa (Susanto, 2014).

Dalam hubungannya dengan belajar, teori Piaget mengacu kepada kegiatan belajar yang harus melibatkan partisipasi siswa. Menurut teori ini pengetahuan tidak hanya sekedar dipindahkan secara verbal tetapi harus dikonstruksi dan direkonstruksi oleh siswa. Sebagai realisasi teori ini, maka dalam kegiatan pembelajaran siswa haruslah bersifat aktif. Contextual Teaching and Learning adalah sebuah pendekatan pembelajaran aktif yang berorientasi pada pembelajaran yang berpusat pada siswa (student centered) (Susanto, 2014).

Pembelajaran dengan model pembelajaran Contextual Teaching and Learning yang diterapkan pada kelas eksperimenmemberikan pengaruh yang cukup baik dalam meningkatkan hasil belajar, sebab permasalahan yang tersaji dalam pembelajaran berkaitan dengan kehidupan nyata siswa. Hal ini sesuai teori Bruner yang menyatakan bahwa proses belajar akan berjalan dengan baik dan kreatif jika guru memberikan kesempatan kepada siswa untuk menemukan suatu konsep, teori, aturan, atau pemahaman melalui contoh-contoh yang dijumpai dalam kehidupannya (Komalasari, 2010). 
Pembelajaran yang sesuai untuk anak Indonesia adalah belajar melalui pengalaman langsung (learning by doing). Model belajar ini memperkuat daya ingat anak dan berbiaya murah sebab menggunakan alat dan media belajar yang ada di lingkungan anak sendiri. Piaget juga mengatakan pengalaman langsung yang memegang peranan penting sebagai pendorong lajunya perkembangan kognitif anak. Pengalaman langsung langsung terjadi secara spontan pada anak sejak lahir hingga usia 12 tahun (Samatowa, 2006).

\section{KESIMPULAN DAN SARAN}

Berdasarkan hasil penelitian dan diskusi, dapat disimpulkan bahwa: (1) Perangkat pembelajaran yang dikembangkan dengan menggunakan pendekatan Contextual Teaching and Learning dinyatakan layak dan dapat digunakan dalam pembelajaran berdasarkan hasil penilaian para ahli; (2) Perangkat pembelajaran yang dikembangkan dengan menggunakan pendekatan Contextual Teaching and Learning dinyatakan praktis berdasarkan hasil analisis lembar observasi keterlaksanaan pembelajaran dan data angket respon siswa; (3) Perangkat pembelajaran yang dikembangkan dengan menggunakan pendekatan Contextual Teaching and Learning dinyatakan efektif berdasarkan peningkatan motivasi belajar; (4) Perangkat pembelajaran yang dikembangkan dengan menggunakan pendekatan Contextual Teaching and Learning dinyatakan efektif berdasarkan peningkatan hasil belajar siswa.

Berdasarkan penelitian yang telah dilaksanakan, maka saran yang diberikan adalah hasil pengembangan perangkat pembelajaran ini dapat dijadikan bahan masukan atau referensi kepada sekolah dalam menentukan kebijakan dan pertimbangan untuk memberikan kesempatan pembelajaran menggunakan pendekatan Contextual Teaching and Learning. Diharapkan guru dapat menerapkan pembelajaran dengan menggunakan pendekatan Contextual Teaching and Learning agar siswa lebih aktif dalam mengikuti pembelajaran dengan mengaitkan apa yang dipelajari dengan pengalaman di kehidupan sehari-hari sehingga pembelajaran menjadi bermakna bagi siswa. 


\section{DAFTAR PUSTAKA}

Amuntu, S., Rede, A., \& Pasaribu, M. (2016). Meningkatkan Motivasi dan Hasil Belajar Siswa Melalui Contextual Teaching And Learning Pada Tema Lingkungan Di Kelas II SDN 2 Talise. E-Jurnal Mitra Sains, 4(3), 28-34.

Anggraeni, T., Sugiyo, \& Kustiono. (2017). The Difference of Ability to Ask, Scientific Attitude, Motivation Before and After Following Contextual Teaching and Learning Model. Journal of Primary Education, 6(3), 248256.

Daryanto, \& Rahardjo, M. (2012). Model Pembelajaran Inovatif. Yogyakarta: Gava Media.

Farida. (2017). Penggunaan Pendekatan Contextual Teaching And Learning (CTL) Pada Pembelajaran IPS Di Sekolah Dasar. Jurnal Inovasi Pendidikan Dan Pembelajaran Sekolah Dasar, 1(1), 78-86.

Komalasari, K. (2010). Pembelajaran Kontekstual: Konsep dan Aplikasi. Bandung: Refika Aditama.

Majid, A. (2013). Strategi Pembelajaran. (P. R. Rosdakarya, Ed.). Bandung.

Manik, I. K., Lasmawan, I. W., \& Marhaeni, A. A. I. N. (2015). Pengaruh Pendekatan Kontekstual terhadap Motivasi dan Perestasi Belajar IPS Siswa Kelas IV SD Negeri 1 Tulamben. E- Journal Program Pascasarjana Universitas Pendidikan Ganesha, 5(1), 1-13.

Rusman. (2014). Model-Model Pembelajaran: Mengembangkan Profesionalisme Guru. Jakarta: Rajawali Press.

Sugiyono. (2012). Metode Penelitian Kuantitatif, Kualitatif, dan R\&D. Bandung: Alfabeta.

Sujana, A. (2014). Pendidikan IPA. Bandung: Rizqi Press.

Suprijono, A. (2014). Cooperative Learning Teori \& Aplikasi PAIKEM. Yogyakarta: Pustaka Pelajar.

Susanto, A. (2014). Pengembangan Pembelajaran IPS di Sekolah Dasar. Jakarta: Prenadamedia Group.

Uno, H. B. (2011). Teori motivasi dan Pengukurannya. Jakarta: Bumi Aksara. 